\title{
An Analysis of the \#FeesMustFall Agenda and Its Implications for the Survival of Education in South Africa: The NWU Mafikeng Campus Writing Centre Experience
}

\author{
UP Ejoke $^{1}$, PC Enwereji ${ }^{2} \&$ JE Chukwuere ${ }^{3}$ \\ ${ }^{1}$ Disease and Lifestyle, North-West University, South Africa \\ ${ }^{2}$ University of Johannesburg, South Africa \\ ${ }^{3}$ North-West University, South Africa \\ Correspondence: Dr. PC Enwereji, University of Johannesburg, South Africa. Tel: 27-61-970-3177.
}

Received: May 16, 2019

doi:10.5430/rwe.v10n3p65
Accepted: June 25, 2019

Online Published: September 26, 2019

URL: https://doi.org/10.5430/rwe.v10n3p65

\begin{abstract}
The \#FeesMustFall-protests were symbolic of unguided social dynamics as stakeholders directly or in directly (indirectly) scramble for escape due to the financial implications that fees increment would engender. South African government is aware of the importance of education in any growing economy as this was demonstrated in the agenda of the post-1994 government in prioritising primary and secondary education, even though the quality of education remained decidedly poor. However, same cannot be said for tertiary Universities in South Africa, the low priority granted to higher education over the past two decades had always been a bone of contention. This paper therefore attempts to interrogate various explanations for fees must fall movement and how this impact on the writing centre at the North-West University, Mafikeng Campus. In contextualizing this problem, the paper employed key elements of Altbach's empirical theory of student movements. Using Focus Group discussion and by means of Atlas-ti statistical package, the paper demonstrated the richness of data available for analysis and reflects on correlated methodological challenges when attempting to understand student movements and the dynamic relationship between the University environment as well as the country-wide movement, the territorial space and that of writing centre experience during and after the protest. The paper concludes by reflecting and suggesting on elements of a possible research agenda on balancing education and economy.
\end{abstract}

Keywords: \#FeesMustFall, student activism, universities, higher education, Mafikeng Writing Centre

\section{Introduction}

Education in South Africa like all other nations of the world is regarded as one of the most critical aspects needed for national regeneration as well as progress. Yet, after 25 years of democracy, very little has changed in the education landscape as South African universities all seem to be facing common challenges. The recent student revolt and activism in the 2015/2016 \#FeesMustFall (No more payment of tuition fees) movement is a testimony to this. The same have been recorded to have significant implication for the survival of education in South Africa and its international ranking (World University Rankings 2017 \& QS world university ranking, 2017), as well as having potential to impact on writing centres, particularly the North-West Mafikeng writing centre.

The \#FeesMustFall movement is a discontent associated with high tuition fees, colonial statues and decolonisation of the curricula in higher education (Calitz \& Fourie, 2016). These are but some of the challenges affecting the institutions and the movement are critically challenging the status quo. Given the broader social consciousness, \#Feesmustfall agenda has been able to marry students' plight with that of the working class. In this light, there are strong potentials that, this rights consciousness and student activism, is capable to filter into other sections of society (Karodia, Soni, \& Soni, 2016). In this regard, Hlophe (2015) hints that "One common factor in the protests is that they call for the political leadership to account and to be responsive to the manifestation of their rights".

It must be noted that, the increasing of tuition fee in higher education is not just a South African case, it is a global phenomenon, as similar challenges have made headlight in countries like Australia, Brazil, Finland, Germany, New Zealand, Thailand, the Netherlands, Poland, Turkey and the United Kingdom; with complaints from academics and 
students across the world over lack of governmental support associated to the rising cost of university fees (Cai \& Kivistö, 2013; Caner \& Okten, 2013; Chapman \& Sinning, 2014; Kwiek, 2013; Marshall, 2016; Ziderman, 2015).

South Africa is not left out from these global trends. The recent \#FeesMustFall protests have not only successfully highlighted government underfunding of higher education but surfaced dissatisfaction with income and service disparities. While, government policies present historically unparalleled challenges and opportunities to educational institutions, particularly to providing equitable academic preparation to all students. The \#FeesMustFall-protests were symbolic of unguided social dynamics of poverty and unequal resources combine to frustrate the needs of the majority stakeholders (e.g. Parents, guardian and care takers) who directly or in directly scramble for escape due to the financial implications that fees increment would engendered (Calitz \& Fourie, 2016).

While some scholars (Doherty \& McIntyre, 2015; Piketty, 2014) argued that the problem facing higher education is unequal access, Shay (2017) links it to the relationship between growth and tension running through policy discourse. Yet, others have discussed the phenomenon under study with regards to the goals and aim of free education (Karodia, Soni, \& Soni, 2016). This paper argues that whatever the reason of the challenge might be, a proper diagnosis is vital, in order to carefully conceptualize the varied problems faced by the majority of students as well as the timely crafting of modalities in solving these issues so as to save education in South Africa. Thus, this paper employs Altbach's empirical theory of student movements to conceptualize student activism, it further discusses higher education in post 1994, then analyses \#FeesMustFall agenda in South Africa, with the aim of indicating its implications on higher education in South Africa and academic support centres, particularly, the North-West University Mafikeng Writing Centre. Another inquiry was made by employing a focused group interviews with the writing consultants to peruse their understanding on the implications of the protest on the Writing Centre. The paper concludes with plausible suggestions embedded in balancing education and economy as a way forward.

\section{Theorising Student Politics and Activism Perspective}

Using Altbach (1964-2006) key elements of Altbach's empirical theory of student movements, this paper attempt to explain the drive of student activism. Altbach conceptualised student activism based on key characteristics of student activism and associated propositions regarding the following terms: causes of student activism; organisation; ideological orientation and outcomes; student backgrounds and identity; context-specific; historical conjunctures in the emergence of student activism and finally the response to student protest by national and University governments. As a result of Altbach successful theoretical contributions in changing and solving the challenges facing European higher education and student demonstrations at both institutions and systems, four testable propositions for theorizing students activism were considered, which are:

- What conditions prompted student activism?

- What are the features of student movements?

- What are the characteristics of student activists?

- What are the impacts of student activism?

At this point, it is needful to operationalise certain terms and as such, 'student' in this paper drawing from Altbach definition shall refer to students studying in higher institutions while excluding those in vocational training colleges and high schools (Altback, 1992). In this study 'student politics' is a concept used to refer to several political activities of students, which could be either formal or informal (Luescher, 2005), ordinary or extraordinary (Pabian \& Minksová, 2011), focused towards society or academia (Altbach, 1966). Student activism is characterised by all kinds of student campaigns, peaceful and violent protest marches (Altbach, 1991). Altbachian questions assist to guide the analysis of student activist movement, with regard to the question that ask:

\subsection{What Conditions Prompted Student Activism?}

Altbach was very clear on this, when he said that:

Where student activism is traditionally accepted as a legitimate element of the political system, it is more likely to have an impact on society.

Altbach (1992) discovered that student activism may be significant as well as influential in industrialised (First or Second World) especially, in nations that have faced a legitimacy deficit - " for example Eastern Europe, Western countries during the 1960s". In contrast, student activism may be challenging and needless in societies operating with open and pluralistic systems of government, (e.g. the United States (Moodie 1999). Furthermore, Altbach, put forward a clear proposition: 
in the established democracies, "student do not see themselves nor are they seen by society as being legitimate political actors"; at least not to the extent this is the case in non-democratic societies. In the 'new' nations, student often played an important part in bringing about national self-determination through their participation in nationalist and liberation movements. Thus, historically, the student movement has established a degree of political legitimacy that allows it to "speak truth to power" with considerable authority (Altbach, 1992).

\subsection{What Are the Features of Student Movements?}

This question deals with academic lifestyle, and how this foster or hinders student activism. While considerable free times on campus afford students enough time to build relationship with like-minded peers, involve in arguments and explore. Conversely, academic studies regulate life and dictate a rigid timetable. In this case, periods of tests and exams can be time taking, thus, making activism the more difficult. Base on this scenario Altbach put forward another proposition:

The proposition here is therefore that the less regulated (or more laissez-faire) the academic life of students is, the more likely student movements emerge and are sustained across several student generations and traditions of activism are developed and maintained (Altbach, 1991)

In addition, at the system level of higher education, Altbach hinted that various characteristics put together are important for understanding student activism, characteristics such as: types of universities, disciplines of study and certain features integral in different national higher education systems. There is no conclusive argument as to the association of student activism to a specific characteristic of any university type (i.e. elites, mass and universal). Importantly, student activism had been observed in all higher schools of learning, even if its meaning may vary (Trow, 2006).

Furthermore, size and heterogeneity of the higher education system was found to have impact on student movement. For example, student activism is totally difficult in the large and heterogeneous American (national) and/or European (supranational) system (Moodie 1999). While in many developing countries, organising a student movement of national impact is much easier.

Also of crucial note is the type, size, prestige and location of universities. In relation to students' backgrounds, student activists tend to come generally from high social economic status families, usually well-educated and more privileged compare to the average student. In addition, they are not only best students in class, but are typically clustered in the best prestigious universities (Altbach 1992). Where they could easily meet with cosmopolitan and activist professors (Altbach 1992). Besides, studying in a University that is situated either in the capital or close "gives students a sense that they are: firstly, at the centre of power" (Altbach 1991); secondly, easy access to information and decision-makers. Thirdly, demonstrations are more likely to receive quick and fast national media coverage and lastly, prompt response due to strategic setting.

Finally, particular faculties and course of discipline are more inclined towards activism than others. Faculty like social sciences and humanities and discipline like mathematics; on the contrary, disciplines like applied and professional fields like commerce, engineering and agriculture are least inclined towards activism (Altbach, 1991; Altbach, 1992; Lipset \& Altbach, 1969). The reason for this pattern can be linked to the fact that (a) social sciences and similar disciplines focus on the study of society and social problems; (b) the subject matters actually affect students and produce more radical views and a more activist inclination; and (c) the structured nature of such courses makes it more difficult for students to 'take a year off' and come back to their studies (Altbach, 1991).

\subsection{What Are the Characteristics of Student Activists?}

From the foregoing, characteristics of student activist has been discussed, they are part of Altbach's 'sociological generalisations' regarding "who are the activists". What matters are: (1) the high social economic status family background and political background (2) minority groups tend to be over-represented among student activists (e.g. Christians in India; Protestants in France; Jews in the United States); and (3) they tend to emanate from specific faculties and departments as well as among the academically best performing students (Altbach, 1991). Therefore, the typical student rebel cannot be said to be a representative of the student body; rather the individual is more likely a part of a small minority of the general student community. 
2.4 What Are the Impacts of Student Activism?

In 1966, Altbach hint that:

\begin{abstract}
"One of the difficulties in analysing student movements is their transitory nature the student community as well as the interests of the students change rapidly. Organizations are often temporary, and leadership fluctuates. The emphasis of the movement's shifts from campus to society and back again at rather regular intervals, and the movement itself can disappear for extended periods of time. Interaction between the educational system, the broader political and economic situation, and the socio-psychological nature of the student community is complex, making any thorough understanding of the role of the students in politics and on the educational establishment difficult." (Altbach, 1966)
\end{abstract}

The effects of student activism is well captured in the above quote, however, Altbach conclude that student 'fluidity' and strains, their rise and demise are problematic to predict.

Sequel to this paper, the analysis of the key questions of Altbach is of great significance of analysing the situation of \#FeesMustFall in South Africa, as statistics reveal below (see Figure 3). Student activist started in what Altbach regarded as 'elite' universities in one of his propositions regarding the typical characteristics of student organisations/movements, where University size and location were impact factors. From Figure 3, it is evident that the movement started from universities such as: Witwatersrand, Pretoria, University of Cape Town (UCT) and University of Kwazulu Natal (UKZN). Moreover, students that attend these mentioned schools are also from high social economic status families and it is expected further that these students are indeed from rich background just as proposed by Altbach when analysing the typical characteristics of student activists in relation to students' backgrounds, while highlighting that student activists tend to come generally from high social economic status families. And this factor is particularly important for this study, as it explains why it was easy for student activism to commence from the 'elite universities' during the much popular \#FeesMustFall in 2015/2017 in South Africa.

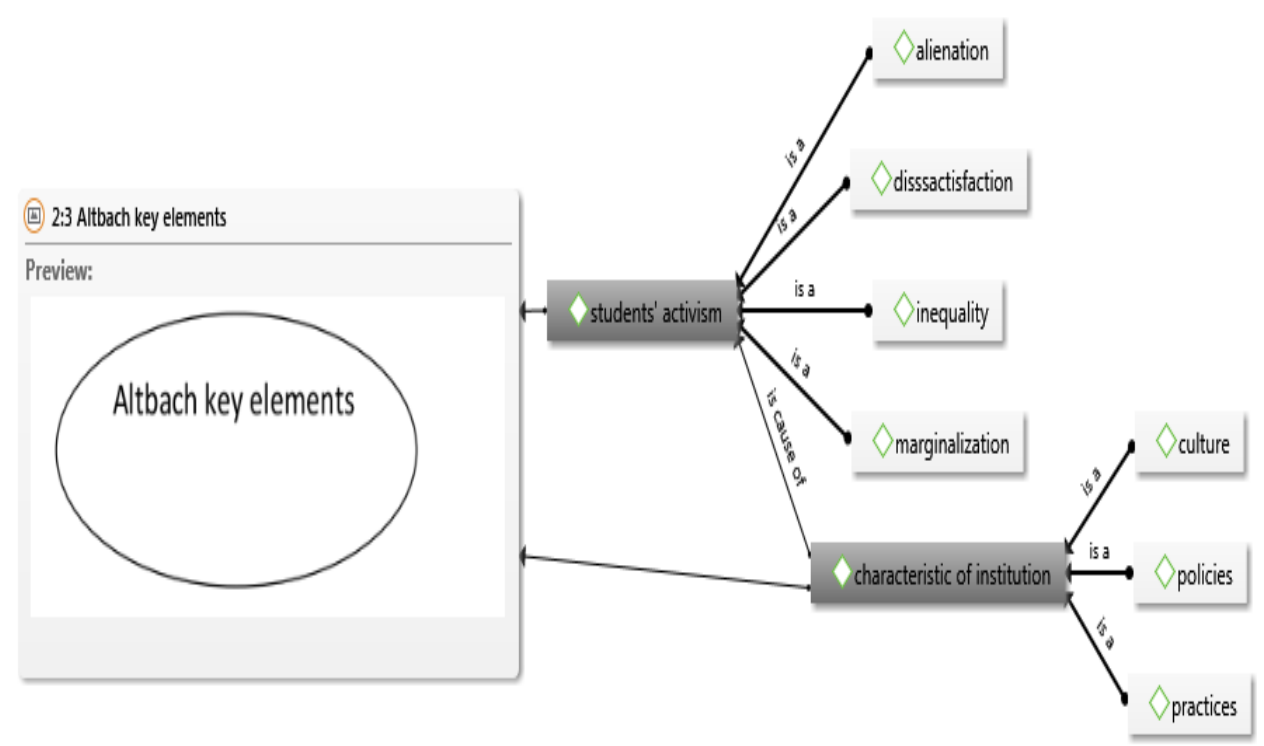

Figure 1. Theoretical framework showing the relationship between students' activism and institutional practices

Conceptually from Figure 1 above, it is expected that students will protest when the culture and practices of the institution they are affiliated with is different from student culture and beliefs, therefore provoking feelings of marginalization, dissatisfaction inequality and alienation.

\title{
3. Higher Education: A Post-Apartheid South African Context
}

Only 23 years after apartheid, South Africa continues to be a highly unequal society even in institutions of higher learning. The status quo has not changed since days of apartheid, as noticed by Naicker, (2016) 'to be black is to be poor, and to be poor is to be black' for the majority of the population. \#FeesMustFall is an outburst of race and class 
divides within majority of the people of South Africa, the dissatisfaction in societal disparity is not limited to university students, but workers and parents used this opportunity to also air their unhappiness (Karodia, Soni, \& Soni, 2016). Despite efforts by the government through policies for the restructuring of higher education in South Africa in 2002, few years after democracy to reduce the numbers of higher education institutions from 36 to 21 , by merging former white Universities and technikons with former black Universities and technikons (Nash, 2006) The Higher Education Institutions remained modulated by class, racial and language divisions. The restructuring as argued by Nash (2006) was meant to provide more focused and stability in the educational sector in South Africa, as a part of a wider move to neo-liberal economic policies as propagated in the rhetoric of ANC government. According to ANC, the justification of the merger was to promote non-racialism and democracy in the form of the new higher education system' within higher education.

However, the dichotomization of higher education into black institutions and white institution further emphasize the unhealthy divisions and frustrations amongst university students, Nash (2006) notes how students from historically black institutions are made to compete for resources on the basis of 'performance pointers' usually set up by a global market, with a strong 'managerial ideology'. According to Nash (2006), this situation lead to the creation of a class of managerial elites entirely detached from their academic colleagues and is no longer answerable to them. More so, the issue of publishing in international journals further indicate and promote what interest academics rather than reflecting on the needs of communities around them, on issues such as: art, music or politics from within those communities (Nash, 2006). After the re-structuring, the evidence in higher education as submitted by Nash (2006) was the proliferation of global knowledge market and network within the academia. Predicting the implication of this approach to higher education, Nash wrote:

What is certain is that those students from a working class background who do gain access to higher education will find themselves in an environment where the needs and values of their communities are alien. Their communities will become objects of knowledge but there will be no place for the idea of a university that empowers working class people or provides them with the skills and resources that enables them to challenge their subjugation themselves.

Presently, from the latest record from Department of higher education and training [DHET] (2013), South Africa has 23 higher institutions, including traditional universities and universities of technology (DHET, 2013). Out of 4 historically white institutions, University of Cape Town (UCT) only recently recorded 51 per cent registered black contact students of which Indian, coloured and black African students are inclusive. In Rhodes University, black registered students totalled 59 per cent, at University of Witwatersrand (WITS) 74 per cent were black and Stellenbosch numbered the lowest with 32 per cent (DHET, 2013). A high significance is the staffing composition which is predominately white. The statistics from DHET reveals the following: WITS was 32 per cent in 2011; UCT was 28 per cent, at Rhodes 20 per cent and at Stellenbosch a mere 18 per cent (DHET, 2013: 14). In University of Pretoria, students joined the \#feesmustfall movement in October 2015; only 46 per cent of students were registered black, with only 20 per cent as black academic staff. Perhaps this was what prompted Shay (2017) to carry out a study in South Africa investigating educational investment towards the ideal future. The results showed that, over the past two decades in terms of 3-year degree, there have been under representation of black, coloured and Indian students and white students are still over-represented in certain higher institutions.

The foregoing reinforce claims about decolonization and transformation of higher education curriculum and staff composition as the students keep saying, 'who teaches matters and what they teach matters more' (Naicker, 2016). The lop-sided statistics of these former white institutions revealed a bigger gulf when compared to historically black institutions. In the latter, over 80 per cent remained predominantly black registered students and staff alike (DHET, 2013). Also disturbing is the wide gap between the numbers of Masters and $\mathrm{PhD}$ graduates emanating from these schools. With higher numbers of graduates coming from the historical white schools (DHET, 2013).

However, Naicker (2016) hints that what prompted the student activism in these historical white school was that over 5-10 years, the demographics of students in these schools (UCT, WITS, Stellenbosch and Rhodes) started changing, particularly among the post graduates. As the number of blacks registered students started growing in these school, direct conflicts between black students' cultural practices and the functionalities of the institutions, which is decidedly white started igniting. Drawing from Altbach empirical theory of student movement, it is expected that under certain conditions, students activism will emerge and the typical characteristics of the institutions can be indicators for student movement to occur, based on this understanding, it is no wonder that the \#FeesMustFall movement in South Africa was institutions location-specific as the movement started from WITS, spread to Pretoria, what Altbach referred to as 'elite Universities' and also certain conditions within the institutions triggered the call for decolonizing the curriculum and the whole system. This was explicitly clear from the manner in which students structured themselves in different 'Elite Universities' and demanded for the removal of statues, for example 
\#RhodesMustFall at UCT, demanding for the bring down of Cecil John Rhodes. Thereafter, Rhodes, Stellenbosch and WITS followed similar part for rejection of representational structures.

Education in post-apartheid South Africa is one sector that is yet to be free of challenges, despite various governmental measures, such as, the policy promoting education for all, (EFA), the Freedom Charter that advocate "the doors of learning must be open to all." (The Freedom Charter, 1956); several discourses by social movements for free and compulsory education during anti-apartheid struggle and inclusion of education as a human right in the constitution. In all of these, \#FeesMustFall protest is an indication that nothing has changed since democracy. Therefore, the protests on the one hand question the very foundations and practices of the liberal University. It brings to reality that after 23 years of democracy, South Africa politicians can no longer rely on their revolutionary credentials because, according to the propaganda of the agenda of \#FeesMustFall 'the time has come to deliver real change'. These students feel marginalised, dissatisfied, excluded and alienated from institutional culture and practices and demand a proper re-structuring which must start from institutional decolonization.

\section{1 \#Fees Must Fall Movement in South Africa}

Post 1994 education continue to generate concerns as well as reflecting the problems and linkages of leadership transition. This is worsened by the expansion of the middle class, increasing inequality, and government policy guaranteeing entry into Universities, for students, regardless of the quality of matriculation results. All these capped government failure of revamping the further education and Training (FET) higher education institutions, into which billions of Rands have been pumped into (Karodia, Soni \& Soni, 2016). This has created great expectations for majority of South Africans and contributed to the social currents of resistance that has now infiltrated the higher education landscape. Education according to Samoff (2008) "has not been the dynamo at the centre of social transformation." Contrarily, Karodia, Soni and Soni (2016) state the need for higher education to become the engine for change, which according to these authors must be immediate, though arguing that this contradiction is borne out of the confusion as to the role of education in maintaining and transforming society. Firstly, after 300 years of colonialism, which is dated more than 50 years of apartheid; secondly, over 23 years of democracy, a time period regarded to be sufficient for transformation in education landscape"

The higher education sector in the recent past in South Africa has suffered from challenges over the years and the common challenges among all students irrespective of their race, social economic status, international or local students prompted one body, forming a movement termed \#FeesMustFall. Cohen (2015) argues that for the first time in South African context, \#FeesMustFall represented a new kind of activist politics having the following characteristics: nonpartisan multicultural, multiracial and multiclass movement; and, it was not only "national but largely leaderless". Similarly, Doherty and McIntyre (2015) state that all these students with one voice protested for better access to tertiary education. The agenda of the movement revealed how politically and socially explosive inequitable access to social services can be. In this regard, Butler-Adam, (2016) analysed the poverty situation in South Africa, by situating the issue of sustaining the financing of higher education without fees increases as well as registration being levied and paid. This is to be considered before the announcement of president Zuma in connection to fees increase, also remembering rising consumer price index - which applies to operating costs and to acquiring intellectual materials with a weak Rand. The value of the unpaid increases needs to be sourced. There is a challenge underway to attempt to ensure that this happens. At the same period, students will want support for the fees that are yet to be paid, money for learning materials; and, of course for living costs.

While few students may be sponsored by their families, majority would have to pay their way through school. Taking into account the unemployment figure of 8.3 million South Africans. With this huge figure, National Student Financial Aid Scheme (NSFAS) will have to do better, in that, more funding will be required as well as better administration strategy within the Fund and within universities. However, acknowledging the recent appointment of Sizwe Nxasana the new Chair of NSFAS as particularly remarkable. Yet, turning the Fund around to cater for the huge application may prove to be a task at least as challenging as managing First Rand (Butler-Adam, 2016), specifically with the situation of underfunding for higher education as indicated by Nkosi (2015a) that "state spending on higher education has dropped at an alarming rate over the years and, government has been critically underfunding institutions and students for years". Additionally, Nkosi reported that higher education department admitted to issues of underfunding universities, though blames was laid on unfavourable economic conditions (Nkosi, 2015). This is further worsened by the Minister of Higher Education's announcement that universities for the 2016 academic year have to find funding between R20 to R50 million to fund universities shortfalls (Karodia, Soni \& Soni, 2016). On the other hand, students are in such a crisis and Zwane (2015) states that "the money for individual students which ought to be used for food goes to their fees, ranging from R1300 to R1600 per month. This may contribute to the system and education will wither further in the years that lie ahead if is not quickly addressed. 
The foregoing challenging atmosphere ignited \#FeesMustFall and in the process have successfully highlighted government underfunding of tertiary education and surfaced dissatisfaction with persistent income and service disparities more generally. The dissatisfaction elicited rage from students, protesting as one body and the result according to Zwane (2015) indicated days of student rage which had the potential to bring higher education in South Africa to a complete standstill in October of 2015. The rage was going on for almost three months and was unabated continuing into 2016. The protest resulted to forced shut down of universities in South Africa with cancellation of exams. The protest is termed "the dark days of students" (Zwane, 2015) [See Figure 3], but this paper would rather term it as "the dark days of South African economy" The dark days torched buildings and destroyed infrastructure worth millions of Rands. The figure below shows the demonstrations by students in Johannesburg.

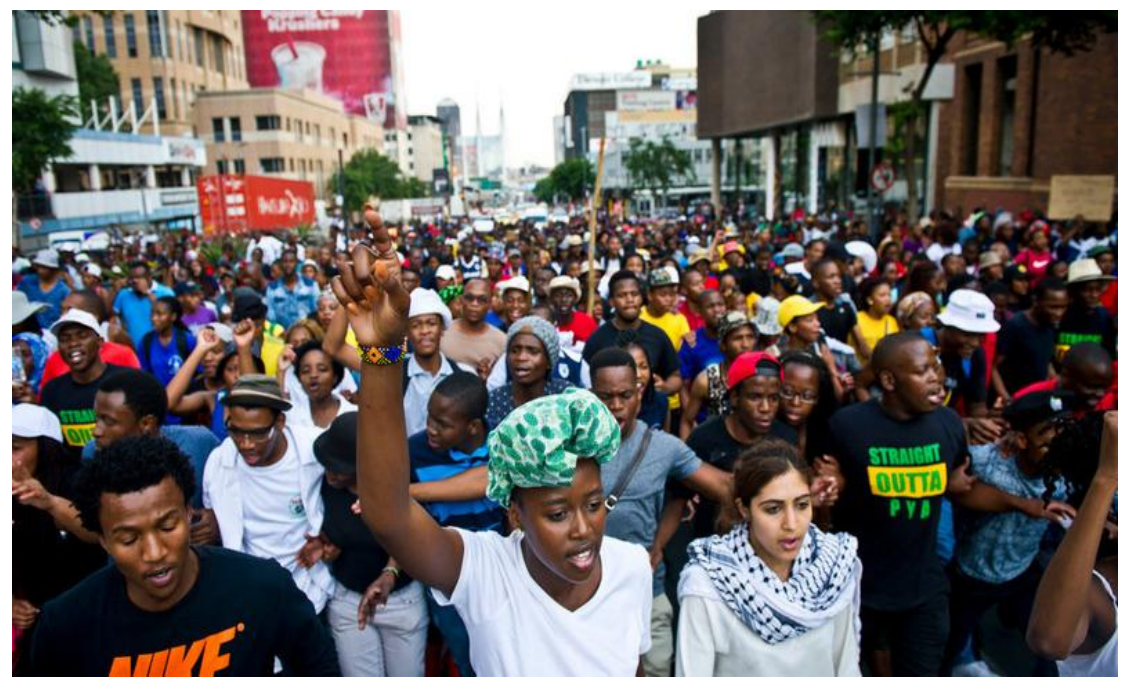

Figure 2. Even if they point their guns at us we are going

Mail \& Guardian (2015)

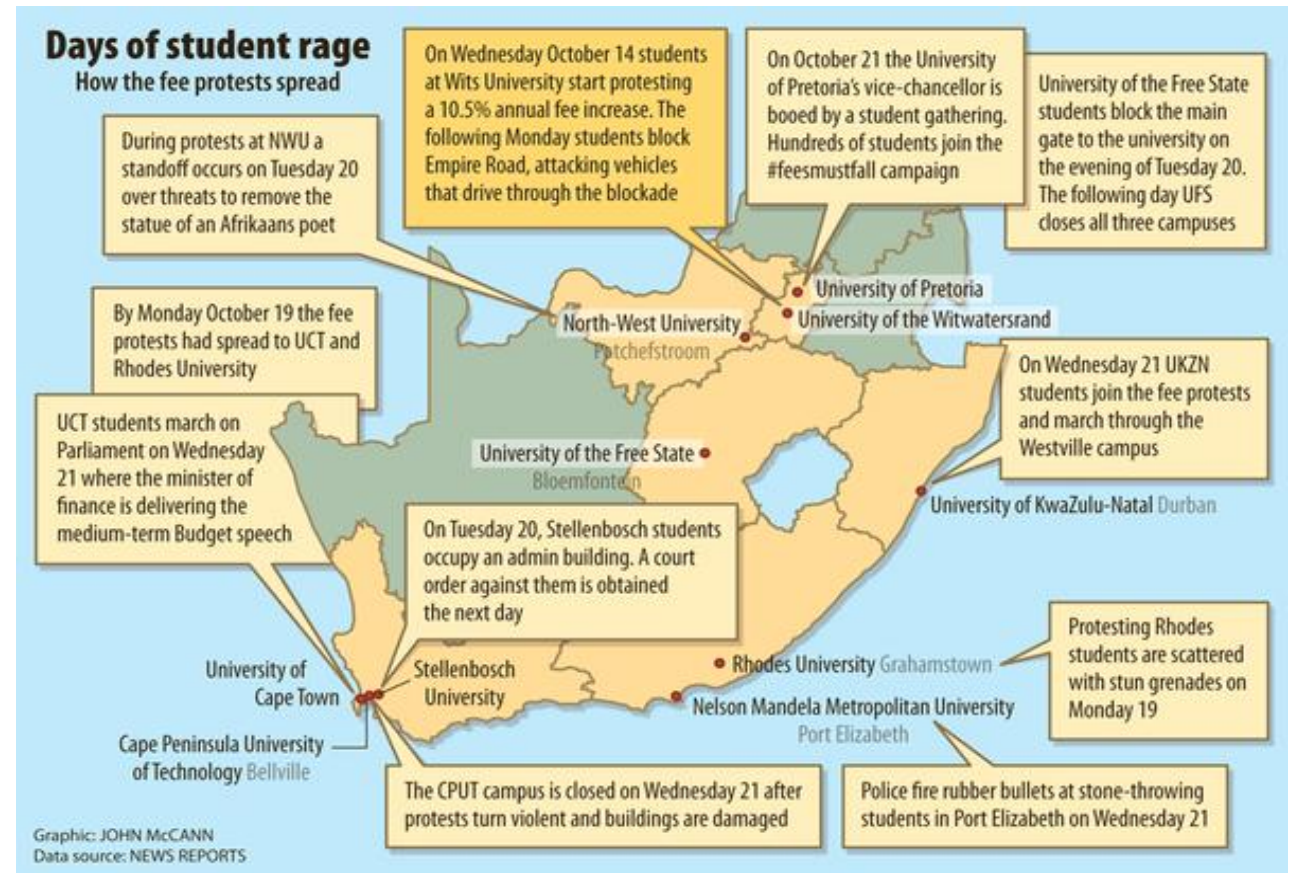

Figure 3. The dark days of students

Source Zwane, 2015. Mail and Guardian, October 23 Johannesburg 


\section{Methodology}

The study employed exploratory qualitative design to achieve objective of the paper. By means of qualitative content analysis, articles were selected from peer-review international scientific journals, Academic search premier, news papers, and magazines based on their relevance to the phenomenon under investigation. The articles were analysed to determine the characteristics and the direction of the discourse of \#feesMustFall. This included defining the codes to be used, the data to be captured by each code, through means of auto-coding that allows search on all textual articles either through text, word, expression and regular expressions. Moreover, text was coded either by exact match, word, sentence, paragraph, chapter and document. And creating quotations from found matches and automatically codes them with the selected code. This generated emerging themes from literature, same was exported into excel spreadsheet. From which further analysis conducted allowed visual representation to be displayed on bar-chart showing not only co-occurring codes from these articles but also their frequencies (see Figure 4). Using ATLAS.ti in this study provided substantial advantage, particularly for its coding function, its ability to analyse enormous qualitative data and its flexibility of exporting data to other tools for further analysis.

Furthermore, the study employed a focused-group interview which were conducted with eight (8) participants from the writing centre to further investigate their experiences during the \#fees must fall protest on the writing centre, Mafikeng Campus. Additional questions such as the academic implications of the protest, measures adopted by the centre to handle the inflow of students and the recommendations to handle such situations were asked. During the focused-group interview session, the interviewers addressed the interviewees as well as introduced the topic and its academic relevance. All the ethical considerations such as anonymity of responses, right to participate and right to exit, protection against harm, reporting of accurate responses and other relevant ethics were duly observed. Figure 4 presents the findings from the literature while Table 1 presents the findings from the focused-group interviews.

\section{Presentation and Discussion of Literature Review Findings}

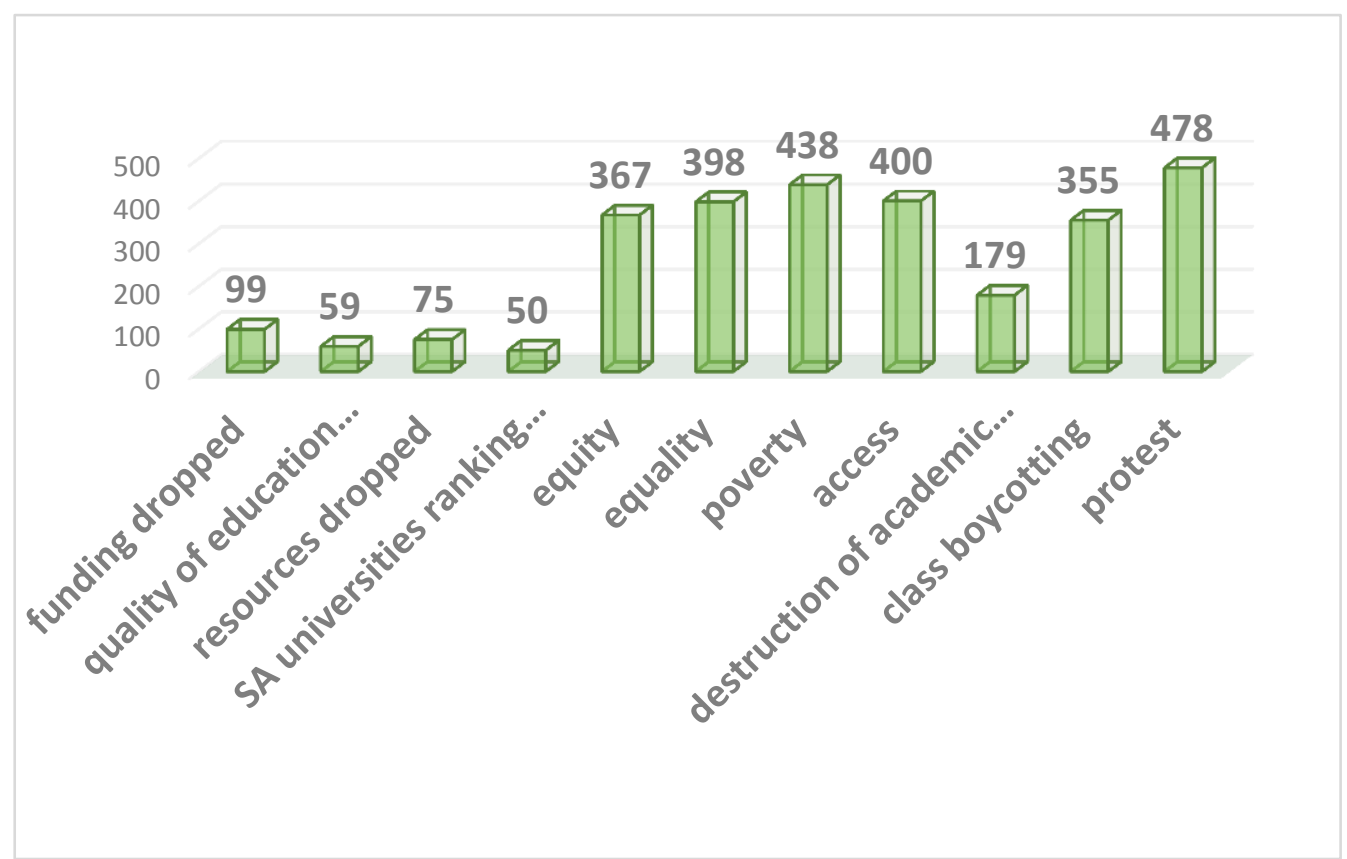

Figure 4. Showing emerging themes with frequencies in literature on the analysis of \#FeesMustFall from 2015-2017

\section{Implications and Discussion of Findings}

\section{- Economy level}

The following observation can be drawn from Figure 4 above: firstly, South African university's global standing dropped significantly in international ranking, part of the reason for this has been linked to fee freezes and funding shortfalls. For example: University of Cape Town dropped 20 places and is present at the 191st spot on the list for the 2016/2017 period, with Wits University dropping to the $359^{\text {th }}$ position having dropped a notable 28 places. Every 
South African university on the list dropped significantly in ranking, some universities even dropped by an astonishing 100 places. North West University as well as University of the Western Cape made their debut on the list, being ranked in the 700+ category. Additionally, University of Pretoria left from the 501-550 category to 551-600 category. The University of KwaZulu-Natal went from being ranked in the 551-600 category in 2015 to now being ranked in the 651-700 category (Yamkela, 2016; Qs World University Ranking, Times Higher Education 2016/17).

The above undeniably reflect a significant loss in any system, as ranking is a vital sign and the potential of a country's capacity to contribute in world science and the global economy. In the book titled 'Ranking and the reshaping of higher education' Hazelkorn (2015) noted that internationalization is a priority for both government and higher education, and ranking is presently deem necessary as the basis of economic growth, accountability and transparency. Ranking is the manifestation of "battle for excellence". Though, it has been argued that, it is unlikely that the protest was responsible for affecting the ranking. Rather, decades of government under-funding was claimed to be a causal factor (The conversation, 2016).

Funding was another emerging theme linked to the discourse of \#FeesMustFall, the deputy vice-chancellor at the University of Cape Town (UCT), shared some of the content from a memorandum handed to higher education which states:
"We believe that government has not acted decisively to ensure sustainable and adequate funding to address the systemic crisis in the higher education sector. Government has placed an undue burden on students, parents and universities to fund higher education."

The VC went on to say while government has increased the amount of money allocated to universities. The amount has declined from $49 \%$ in 2000 to $40 \%$ in 2012 without the consideration of educational inflation which also have its own role. The VC stressed that, funding has a direct consequence on several indicators used to measure performance in world university rankings. He justified the low ranking to less governmental funding, he argues that less funding impact on staff-student relationship; with universities; top staff, who produce the most papers, leaving for more lucrative salaries abroad. Due to inability for Universities to send their academics to many conferences, the result then is fewer conference papers (The conversation, 2016).

Thirdly, \#FeesMustFall movement impacted on revenue generated from higher education because as ranking dropped, revenue was immediately affected as stated by Ben Sowter, the head of research at the QS intelligence unit, Ben said that:

This year's rankings imply that levels of investment are determining who progresses and who regresses. Institutions in countries that provide high levels of targeted funding are rising. On the other hand, Western European nations making or proposing cuts to public research spending are losing ground to their US and Asian counterparts....... South African universities have been experiencing funding shortfalls for years and that "fee freezes" would not make the situation any better. (Destiny, 2016)

Fourthly, academic properties were destroyed worth over R460m from 18 varsities in South Africa. As indicated in the chart, the frequencies of protest which according to literature was majorly violent, hence, it is not surprising that such worth of properties in value was destroyed. The University of KwaZulu-Natal received the hardest hit. The following are some of the reported losses:

1) Buildings destroyed at UKZN, were a coffee shop, the senate chamber, an examination hall, a building that houses risk management staff, a portion of the law library and a hostel's reception area.

2) The main auditorium was burnt at University of Johannesburg and few windows in a student residence

3) At North-West University, the main gate, monitors and cameras were destroyed at Mafikeng campus; windows were demolished in buildings across campuses; the student cafeteria; the administration building; the science centre; the bursary office as well as the entrance to the house parents' residence at the suffered damages.

4) Other losses included, burnt vehicles and buses at Durban University of Technology; University of Zululand; doors and windows were damaged at the Great Hall at the University of the Witwatersrand; Sol Plaatje University in Northern Cape. However, some other universities confirmed that they had not suffered great loss.

Presentation and discussion of focused group interviews with the writing consultants, NWU Mafikeng Center

The following Table presents the responses by the participants on their experiences during the \#fees must fall protest. 
Table 1. Themes and categories of participants' responses on \#fees must fall protest

\begin{tabular}{|c|c|}
\hline Themes & Categories \\
\hline Experiences during the protest & $\begin{array}{l}\text { - No contingency plans for such incident and to handle } \\
\text { consultations } \\
\text { - Work over load, WC turned into "Fix shop" }\end{array}$ \\
\hline Academic implication during the protest & $\begin{array}{l}\text { - } \text { Quality of studies somewhat affected due to rush } \\
\text { - } \text { Shortage of resources due to damages } \\
\text { - } \text { Overcrowding of students at the centre } \\
\text { - } \quad \text { Declined performance of the students } \\
\text { - } \quad \text { Conferences reduced }\end{array}$ \\
\hline $\begin{array}{l}\text { Measures by which the implications were } \\
\text { handled }\end{array}$ & $\begin{array}{l}\text { - Overtime for the consultants } \\
\text { - Saturday classes }\end{array}$ \\
\hline $\begin{array}{l}\text { Recommendations to the University } \\
\text { governing bodies and the students' } \\
\text { activist }\end{array}$ & $\begin{array}{l}\text { University governing body } \\
\text { - Engage other knowledgeable Postgraduates students } \\
\text { - } \text { as consultants } \\
\text { - } \text { Pentracting other external consultants if possible } \\
\text { - Unilateral decision making and effective } \\
\text { Students } \\
\text { - } \text { Reach at a consensus with the government and the } \\
\text { - University governing body } \\
\text { - Ase dialogue } \\
\text { Avoid destruction and embark on a peaceful protest }\end{array}$ \\
\hline
\end{tabular}

\section{Discussion of Focused-Group Results}

The results of the focused-group interviews conducted with the writing consultants were summarised to give a comprehensive understanding of the study.

\section{Experiences during the protest}

During the interview session the interviewers asked to know the participants' experiences during the \#feesmustfall protest. One of the participants said "During the protest there were no contingency plans made for such incident and to handle consultations. The students were clueless and there was no improved communication means for consultations which had other academic implications" Another participant added "The incident resulted to work overload at the writing as the centre was turned to a "fix shop".

\section{Academic implication during the protest}

As it was noted that the \#feesmustfall protest have some academic implications on the students and the writing centre as well, the interviewers progressed to know those implications from the participants. One of the participants said "The quality of studies were reasonably affected due to rush by the lecturers in order to cover their syllabus" On the aspect of the writing centre, another participant avowed thus: "There were shortage of resources in the writing centre due to extensive damages caused by the students within the University community". Furthermore, another participant mentioned the following: "The writing centre experienced overcrowding of students that came for writing 
consultations while students' performances declined due to rush by the lecturers in order to cover the syllabus". One of the experienced consultants expressed the following "The sponsorship for conferences were reduced due to issues related to finance and time"

\section{Measures by which the implications were handled}

The study progressed by asking the participants the measures employed to handle the implications of \#fees must fall protest on the Writing Centre. All the participants attested the following: "We really worked for overtime in the centre to ensure that we reasonably cover the syllabus, also we had to call for Saturday consultations after the protest which helped the students to improve with their studies".

\section{Participants' recommendations to the University governing bodies and the students' activist}

The study sought for a measure to improve the stability of academic system in South African Universities, the interviewers asked for recommendations from the writing consultants. To the University governing body, the participants recommended that "The University governing board should engage other knowledgeable postgraduate students as consultants or engage other external consultants to handle student consultations" Another participant added that the school governing authority should engage the students in a peaceful dialogue as well as employing effective communication during such incidence.

To the students' activists, the consultants avowed that "The students should endeavour to reach at a peaceful resolution with the government and the school governing bodies, and where such dialogue fails, students should embark on a peaceful protest while they should desist from destroying of government and school properties".

\section{Balancing Education with Economy: A Way Forward}

As much as \#FeesMustFall is aimed towards a good course, this paper is an attempt to understand student movements and the dynamic relationship between the University environment as well as the country-wide movement, the territorial space and the writing centre (WC) space. This paper argues for a proper diagnosis to arrest the educational crisis that \#FeesMustFall may engender, as this will save education in South Africa.

Writing Centres (WCs) offer a space within the University for supporting and augmenting learning in higher institutions. Effectiveness of operations can only happen in a conducive environment and the philosophies of majority of WCs, NWU Mafikeng WC inclusive is that 'a conducive environment is key in constructing knowledge and writing requires vested time and energy because writing is a process'. Against this understanding, WCs are not 'fix shops' whereby desperate students can run to fix their assignments due to time factor and implication created by \#FeesMustFall. This was the case at the NWU Mafikeng campus after \#FeeMustFall and re-opening of the university in 2015/2016. With regard to the quality of studies which was affected due to rush during the \#fees must fall protest, shortage of resources due to damages, overcrowding of students at the centre, declined performance of the students, decrease in conferences and research output, this paper submits a need to balance education with economy as a way forward.

Balancing education with economy becomes a crucial submission of this paper, in that, education in post 1994 is beginning to sink after the student protest, this is evident in the report of world times (2016/2017) which revealed a significant fall in South African universities ranking. Such red light is an indication for South African government to readdress educational policies and also with urgency. With this regards, Karodia, Soni, and Soni (2016) insisted for free education for all, according to these authors education is a public good and thus government responsibility is to make education free for all. In similar circumstances, it has been noted in Mexico when students demanded for free education and Mexican government consented.

In as much as free education may be a brilliant idea, psychologists are of the view that, what is given totally free, often is not revered, therefore, the danger associated with this is that individuals tend not be take education seriously, even those that attempt to be serious, may not see the value in it, after all, it is 'free'. But, the government of South Africa however should realize the importance of education to the economy and devise means to foster education in the country knowing that central to a successful nation is 'education'. Australia has tapped into this vision and invested hugely in education according to the budget speech given in 2016 by Simon Birmingham the prime minister of Australia said the budget allocation for education section has increased as more funding is realised to universities and training more than before not neglecting early childhood care, primary and high schools. At the same time the Australian government maximises other sectors creating a balance in the economy. This is key to any society, the ability to balance all sectors. While it was noted that South African government have increased subsidies to all 26 public universities to the tune of R26.2 billion, the allocation was stated to be insufficient to even cover operational costs let alone other academic functioning. Furthermore, state funding accounts for only 40 percent of universities ${ }^{\text {ce }}$ 
budgets Nkosi (2015a), additionally, South Africa gives 0.7 percent out of its gross domestic product (GDP) on higher education (Karodia, Soni, and Soni (2016). This is an obvious imbalance and inequality of allocation of funding within the sectors of the economy. Nkosi (2015a) hints that "state spending on higher education has dropped at an alarming rate over the years and, government has been critically underfunding institutions and students for years." Due to underfunding, categorization for eligibility becomes the order of the day in some institutions of learning.

Conceptually, Altbach (1991) theory implies that this categorization on the basis of eligibility may result to student activism. As it is likely that protest will occur under various characteristics (See Figure 1). At the institutional level and system level, it is expected that students may register their dissatisfaction, alienation and marginalisation when they perceive disparity based on institutional cultures and functionalism.

\#FeesMustFall movement of 2015-2016 in South Africa have challenged the status quo of education landscape as well as unravel the disparities existing in the country after 25years of democracy. The movement have impacted on the educational ranking of majority of South African universities, education quality within the country and WC centres inclusive to mention a few. The \#FeesMustFall arouses the curiosity of the public, academics and the government. This perhaps is significant as this curiosity can pave way for plausible solutions.

\section{References}

Altbach, P. G. (1966). Students and Politics. Comparative Education Review, 10(2), 175-187. https://doi.org/10.1086/445214

Altbach, P. G. (1991). Student Political Activism. In Altbach, P. G. (Ed.), International Higher Education: An Encyclopedia (pp. 247-260). New York and London: Garland.

Altbach, P. G. (1992). Politics of Students and Faculty. In Clark, B. R., \& Neave, G. (Eds.), The Encyclopaedia of Higher Education. New York: Pergamon.

Birmingham, S. (2016). The prime minister of Australia Budget speech. Retrieved June 20, 2017, from http://webcache.googleusercontent.com/search?q=cache:http://www.theaustralian.com.au/business/simon-birmi ngham-balance-education-with-strong-economy/news-story/6941d2deb7b4fd4a 1839d3b8f7d10244

Butler-Adam, J. (2016). What really matters for students in South African higher education?. South African Journal of Science, 112(3-4), 1-2. https://doi.org/10.17159/sajs.2016/a0151

Cai, Y., \& Jussi, K. (2013). Tuition Fees for International Students in Finland Where to Go From Here?. Journal of Studies in International Education, 17(1), 55-78. https://doi.org/10.1177/1028315311429001

Calitz, E., \& Fourie, J. (2016). The historically high cost of tertiary education in South Africa. Politikon, 43(1), 149-154. https://doi.org/10.1080/02589346.2016.1155790

Caner, A., \& Cagla, O. (2013). Higher Education in Turkey: Subsidizing the Rich or the Poor?. Economics of Education Review, 35, 75-92. https://doi.org/10.1016/j.econedurev.2013.03.007

Chapman, B., \& Mathias, S. (2014). Student Loan Reforms for German Higher Education: Financing Tuition Fees. Education Economics, 22(6), 569-588. https://doi.org/10.1080/09645292.2012.729327

Doherty, J., \& McIntyre, D. (2015). \#FeesMustFall and the campaign for universal health coverage. SAMJ: South African Medical Journal, 105(12), 104-1015. https://doi.org/10.7196/SAMJ.2015.v105i12.10339

Hazelkorn, E. (2015). Rankings and the reshaping of higher education: The battle for world-class excellence. Springer. https://doi.org/10.1057/9781137446671

Hlophe, D. (2015). Higher education dream deferred. The Sunday Independent. Dispatches. Johannesburg, Republic of South Africa, p. 13.

Karodia, A. M., Soni, D., \& Soni, P. (2016). Wither Higher Education in the Context of the Fees mustfall Campaign in South Africa. Research Journal of Education, 2(5), 76-89.

Kwiek, M. (2013). From System Expansion to System Contraction: Access to Higher Education in Poland. Comparative Education Review, 57(3), 553-576. https://doi.org/10.1086/670662

Lipset, S. M., \& Altbach, P. G. (Eds.) (1969). Students in Revolt. Boston: Houghton, Mifflin.

Luescher, T. M. (2005). Student Governance in Africa: Thematic Summary of Key Literature; 2005. University of the Western Cape, African Higher Education Research Online. Retrieved 26 July 2013, from http://ahero.uwc.ac.za 
Luescher-Mamashela, T. M., Kiiru, S., Mattes. R., Mwollo-ntallima, A., Ng'ethe, N., \& Romo, N. (2011). The African University and Democrat.

Marshall, S. (2016). Technological Innovation of Higher Education in New Zealand: A Wicked Problem?. Studies in Higher Education, 41(2), 288-301. https://doi.org/10.1080/03075079.2014.927849

Minksová, L., \& Pabian, P. (2011). Approaching Students in Higher Education Governance: Introduction to the Special Issue. Tertiary Education and Management, 17(3), 183-189. https://doi.org/10.1080/13583883.2011.588720

Moodie, G. (1999). Student Politics in the United States and Britain (Book Review). Minerva, 37, 295-299. https://doi.org/10.1023/A:1004722428197

Naicker, C. (2006). From Marikana to \#feesmustfall: the praxis of popular politics in South Africa. Urbanisation, l(1), 53-61. https://doi.org/10.1177/2455747116640434

Nkosi, B. (2015a). Blade wants state audit of varsities. Mail and Guardian. Education, November 27 to December 3. Johannesburg, Republic of South Africa, 7.

Nkosi, B. (2015b). Trough runneth over for spendthrift Setas. Mail and Guardian, October 23 to 29 used as background reading. Johannesburg, Republic of South Africa, 10.

Pabian, P., \& Minksová, L. (2011). Students in Higher Education Governance in Europe: Contrasts, commonalities and controversies. Tertiary Education and Management, 17(3), 261-273. https://doi.org/10.1080/13583883.2011.588722

Piketty, T. (2014). Capital in the twenty-first century. Cambridge, MA: The Belknap Press of Harvard University Press. https://doi.org/10.4159/9780674369542

Samoff, J. (2008). Bantu Education, People's Education, Outcomes - Based Education. A Forward to Everard Weber's Book (Ed.), Educational Change in South Africa. Sense Publishers: Rotterdam. Netherlands.

Shay, S. (2017). Educational investment towards the ideal future: South Africa's strategic choices. South African Journal of Science, 113(1-2), 1-6. https://doi.org/10.17159/sajs.2017/20160227

The conversation. (2016). SA universities drop in global rankings. Retrieved June 18, 2017, from https://theconversation.com/africa

Trow, M. (2006). Reflections on the Transition from Elite to Mass to Universal Access in Modern Societies since WWII. In Forest, J. F., \& Altbach, P. G. (Eds.), International Handbook of Higher Education: Part One: Global Themes and Contemporary Challenges. Dordrecht: Springer.

World University Rankings. (2017). Retrieved June 15, 2017, from https://www.timeshighereducation.com/world-university-rankings/2017/world-ranking

Ziderman, A. (2015). Student Loans in Thailand: From Social Targeting to Cost Sharing. International Higher Education, 42, 6-8. https://doi.org/10.6017/ihe.2006.42.7883

Zwane, T. (2015). Even if they point their guns at us. Mail and Guardian. \#FeesMustFall. October 23 to 29. Johannesburg, Republic of South Africa, 6. 